$\underline{\text { Article }}$

\title{
Synthesis of Neoflavonoids: 4-(4'-methoxyphenyl)-
}

\section{3,4-dihydrocoumarins}

\author{
Maria Zeneide Barbosa Bezerra ${ }^{a}$, Maria Iracema Lacerda Machado ${ }^{a}$, Selene \\ Maia de Morais ${ }^{a}$, and Raimundo Braz-Filho ${ }^{b}$ \\ ${ }^{a}$ Laboratório de Produtos Naturais, Departamento de Química Orgânica e Inorgânica, \\ Universidade Federal do Ceará, Campus do Pici, C.P. 12200, \\ 60021-970 Fortaleza - Ce, Brazil \\ ${ }^{b}$ Setor de Produtos Naturais, LTA, CCTA, Universidade Estadual do Norte \\ Fluminense, 28015-620 Campos - RJ, Brazil
}

Received: January 1, 1996

\begin{abstract}
Os neoflavonóides 7-hidroxi-5-metil-4-(4'-metoxifenil)-3,4-diidrocumarina (1), 5-hidroxi-7-metil-4-(4'-metoxifenil)-3,4-diidrocumarina (2), 5-metil-7-O-cumaroil-4(4'-metoxifenil)-3,4-diidrocumarina (3), 5-hidroxi-4-(4'-metoxifenil)- $\alpha$-pirano -(6",5":7,8)-3,4- diidrocumarina (7) e 7-pentadecil-4-(4'-metoxifenil)-3,4-diidrocumarina (8) foram sintetizados por condensação, catalisada pelo tricloreto de alumínio, entre o cloreto do ácido 4-metoxicinâmico com orcinol, 5,7-dihidroxicumarina e cardanol hidrogenado. Os produtos das reações foram caracterizados com base nos dados espectrais de $\mathrm{RMN}{ }^{1} \mathrm{H} \mathrm{e}{ }^{13} \mathrm{C}$, usando-se principalmente a técnica de espectroscopia nOe diferencial.
\end{abstract}

The neoflavonoids 7-hydroxy-5-methyl-4-(4'-methoxyphenyl)-3,4-dihydrocumarin (1), 5-hydroxy-7-methyl-4-(4'-methoxyphenyl)-3,4-dihydrocoumarin (2), 5-methyl-7-O -coumaroyl-4-(4'-methoxyphenyl)-3,4-dihydrocoumarin (3), 5-hydroxy-4(4'-methoxyphenyl)- $\alpha$-pirano-(6",5":7,8)-3,4-dihydrocoumarin (7), and 7pentadecyl-4-(4'-methoxyphenyl)-3,4- dihydrocoumarin (8) were synthesized via the $\mathrm{AlCl}_{3}$-catalyzed condensation of 4-methoxycinnamic acid chloride with orcinol, 5,7-dihydroxycoumarin and hydrogenated cardanol. The compounds were characterized on the basis of their ${ }^{1} \mathrm{H}$ - and ${ }^{13} \mathrm{C}-\mathrm{NMR}$ spectroscopic properties, including nOe difference spectroscopy.

Keywords: 4-(4'-methoxyphenyl)-3,4-dihydrocoumarins, synthesis, spectral data

\section{Introduction}

Neoflavonoids ${ }^{1}$ include the important derivatives 3,4-dihydro-4-aryl-coumarins. Some of these display pharmacological properties, such as those of bactericide ${ }^{2}$, molluscicide ${ }^{3}$, and insecticide ${ }^{4}$. The 4-aryl-3,4-dihydro coumarins have mainly been prepared by two methods: Pechmann condensation of an acetophenone and benzoylacetic acid $\left(\mathrm{ArCOCH}_{2} \mathrm{COOH}\right)^{3,5}$, and $\beta$-addition of a phenolic compound to a cinnamic acid ${ }^{6}$.
The condensation of cinnamic acids with phenols to yield 4-phenyl- and 4-aryl-dihydrocoumarins is well known, and has been reported by Simpson and Stephen ${ }^{6}$, who pointed out that good yields are generally obtained when the reaction between cinnamic acid and phenols is carried out by boiling with concentrated hydrochloric acid. Krajnak et al. ${ }^{7}$ found that $72 \%$ vv sulfuric acid at $160{ }^{\circ} \mathrm{C}$ was very effective for condensing cinnamic acid with p-cresol and p-methoxy-phenol. The condensation of phenols with cinnamic acid in the presence of polyphosphoric

- Professor Emérito - UFRRJ, Professor Honoris Causa - UFC. 


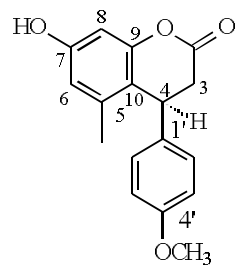

1<smiles>Cc1cc(O)cc(O)c1</smiles>

Orcinol 4<smiles></smiles>

$7 \mathrm{R}=\mathrm{H}$

7a $\mathbf{R}=\mathrm{Me}$

$7 \mathbf{b} \mathbf{R}=\mathrm{Ac}$

acid led to the formation of chalcones and flavanones, and with 4-methoxycinnamic acid the products were 4-(4-methoxyphenyl)-3,4-dihydrocoumarins and 7-methoxycoumarin which was formed through an intramolecular conversion of 4-methoxycinnamic acid ${ }^{8}$.

This paper reports the synthesis of new 4-(4-methoxyphenyl)-3,4-dihydro-coumarins via the condensation of 4-methoxycinnamic acid with natural and synthetic phenols in the presence of aluminium trichloride.

\section{Results and Discussion}

Some 4-(4-methoxyphenyl)-3,4-dihydrocoumarins were syn the sized by $\beta$-addition of different phenols with 4-methoxycinnamic acid under milder conditions than those earlier reported. Aluminium trichloride was added to the phenol dissolved in carbon disulfide, followed by the addition of 4-methoxycinnamic acid chloride at room temperature. 4-methoxycinnamic acid was prepared by the reaction of anysaldehyde and malonic acid in the presence of pyridine ${ }^{9}$. The corresponding 4-methoxycinnamic acid chloride was obtained using oxalyl chloride dissolved in to-
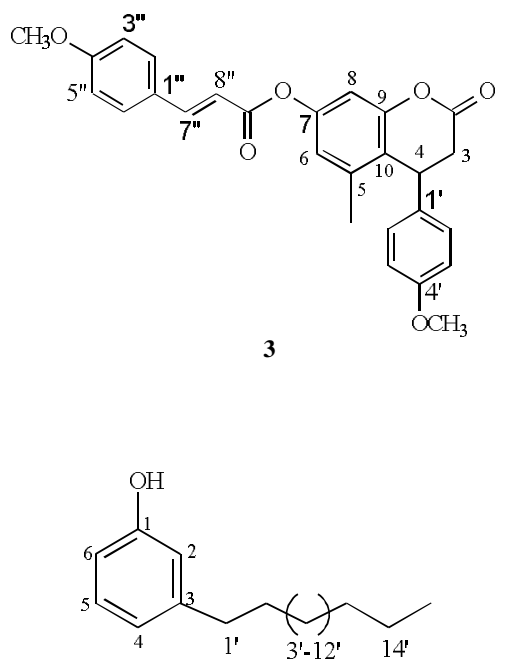

Hydrogenated cardanol 6

luene ${ }^{10}$. The following phenols were used: orcinol (4), 5,7-dihydroxycoumarin (5), and hydrogenated cardanol (6, 3-pentadecylphenol).

The condensation of orcinol (4) with 4-methoxycinnamic acid produced a mixture of two constitutional isomeric neoflavonoids: 7-hydroxy-5-methyl -4-(4-methoxyphenyl)-3,4-dihydrocoumarin (1) and 5-hydroxy-7-methyl-4-(4-methoxyphenyl)-3,4-dihydroco umarin (2), which were chromatographically separated. A third compound was identified as 7-O- (4'-methoxycinnamoyl)-5-methyl-4-(4-methoxyphenyl)-3,4-dihydroc oumarin (3). Table 1 summarizes ${ }^{1} \mathrm{H}$ and ${ }^{13} \mathrm{C}-\mathrm{NMR}$ spectral data of the three compounds (1-3). The difference in the chemical shifts of the carbon atoms of the methyl group at C-5 of (1) ( $\delta c 18.75)$ and at C-7 of $2(\delta c 21.27)$ revealed the upfield shift produced by the $\gamma$-effect $(\Delta \delta \mathrm{c}=18.75(\mathbf{1})$ $21.27(\mathbf{2})=-2.52 \mathrm{ppm}$ ) of carbon $\mathrm{C}-4$ in (1). An analogous $\gamma$-effect $(\Delta \delta c=18.86(3)-21.27(2)=-2.41 \mathrm{ppm})$ was observed in the methyl carbon at $\mathrm{C}-5$ of (3) (Table 1). The minor chemical shift of the carbon C-4 ( $\delta \mathrm{c} 34.21)$ in (2), when compared to the corresponding values of $\mathbf{1}$ ( $\delta \mathrm{c} 36.64)$ and 
(3) ( $\delta \mathrm{c} 37.12$ ), was used to confirm this deduction, since these results are in accordance with the major $\gamma$-effect of a hydroxy function in comparison with a methyl group ${ }^{11}$ (Table 1). Additional confirmation was obtained by homonuclear nOe difference spectra $\left({ }^{1} \mathrm{H}^{1} \mathrm{H}\right\}$-nOe $)^{11,12}$, since only the irradiation of the $\mathrm{H}-4$ signal caused an enhancement effect $(\mathrm{nOe}=8 \%$ ) in the methyl group signal $\left(\delta_{\mathrm{H}} 2.07, \mathrm{~s}, \mathrm{Me}-5\right)$ for compound (1).

5,7-Dihydroxycoumarin (5) was prepared by the reaction of phloroglucinol and ethyl propiolate $\left(\mathrm{HC} \Leftarrow \mathrm{CCOOCH}_{2} \mathrm{CH}_{3}\right)$ in the presence of zinc chloride ${ }^{13}$.
Ethyl propiolate was synthesized using propiolic acid and dry ethanol in the presence of sulfuric acid ${ }^{14}$. The reaction of the coumarin 5 with 4-methoxycinnamic acid chloride led to the formation of compound 7. The comparison of the NMR spectral analysis of 7 with the corresponding spectroscopic data of its methylated (7a) and acetilated (7b) derivatives (Table 2 ) allowed the definition of its chemical structure as 5-hydroxy-4-(4'-methoxyphenyl)- $\alpha$-pirano$(6 ", 5 ": 7,8)-3,4$-dihydrocoumarin. The presence of the hydroxyl group at C-5 of 7 was deduced by downfield shifts observed for the signals of H-6 $\left[\Delta \delta_{\mathrm{H}}=6.97(\mathbf{7 b})\right.$ -

Table 1. ${ }^{1} \mathrm{H}(200 \mathrm{MHz})$ and ${ }^{13} \mathrm{C}(50 \mathrm{MHz})$ NMR spectral data for compounds $\mathbf{1}, \mathbf{2}$ and $\mathbf{3}\left[\mathrm{CDCl}_{3}\right.$ as solvent, TMS as internal standard, chemical shifts in $\delta(\mathrm{ppm})$, and coupling constants $(\mathrm{J})$ in Hertz $]^{*}$.

\begin{tabular}{|c|c|c|c|c|c|c|}
\hline & \multicolumn{2}{|r|}{1} & \multicolumn{2}{|c|}{2} & \multicolumn{2}{|c|}{3} \\
\hline & $\delta \mathrm{c}$ & $\delta_{\mathrm{H}}$ & $\delta \mathrm{c}$ & $\delta_{\mathrm{H}}$ & & \\
\hline 2 & 168.91 & - & 167.82 & - & 166.98 & \\
\hline 3 & 38.01 & $\begin{array}{c}3.02 \\
(\mathrm{dd}, \mathrm{J}=15.1 ; 5.4)\end{array}$ & 37.23 & $2.97(\mathrm{~d}, \mathrm{~J}=4.6)$ & 37.64 & $3.1-2.9(\mathrm{~m})$ \\
\hline & & $2.99(\mathrm{dd}, \mathrm{J}=15.1 ; 2.8)$ & & & & \\
\hline 4 & 36.64 & $4.27(\mathrm{dd}, \mathrm{J}=5.4 ; 2.8)$ & 34.21 & $4.49(\mathrm{t}, \mathrm{J}=4.6)$ & 37.12 & $\begin{array}{c}4.33 \\
(\mathrm{dd}, \mathrm{J}=2.2 \text { and } 6.3)\end{array}$ \\
\hline 5 & 137.98 & & 152.72 & - & 137.91 & - \\
\hline 6 & 113.94 & $6.52(\mathrm{~d}, \mathrm{~J}=2.2)$ & 110.17 & 6.40 (br s) & 119.62 & $6.43(\mathrm{~s})$ \\
\hline 7 & 155.93 & - & 139.67 & - & 150.35 & - \\
\hline 8 & 102.04 & $6.59(\mathrm{~d}, \mathrm{~J}=2.2)$ & 112.40 & 6.55 (br s) & 108.75 & $6.51(\mathrm{~s})$ \\
\hline 9 & 152.41 & - & 152.55 & - & 152.33 & - \\
\hline 10 & 115.08 & - & 109.60 & - & 120.94 & - \\
\hline 1 ' & 132.40 & - & 132.78 & - & 131.68 & - \\
\hline $2^{\prime}, 6^{\prime}$ & 127.85 & $6.93(\mathrm{~d}, \mathrm{~J}=8.7)$ & 127.88 & $7.04(\mathrm{~d}, \mathrm{~J}=8.7)$ & 127.95 & $6.96(\mathrm{~d}, \mathrm{~J}=8.3)$ \\
\hline $3^{\prime}, 5^{\prime}$ & 114.37 & $6.77(\mathrm{~d}, \mathrm{~J}=8.7)$ & 114.43 & $6.78(\mathrm{~d}, \mathrm{~J}=8.7)$ & 114.39 & $6.79(\mathrm{~d}, \mathrm{~J}=8.3)$ \\
\hline $4^{\prime}$ & 158.60 & - & 158.80 & - & 158.81 & - \\
\hline Me-5 & 18.75 & $2.07(\mathrm{~s})$ & - & - & 18.86 & $2.17(\mathrm{~s})$ \\
\hline Me-7 & - & - & 21.27 & $2.28(\mathrm{~s})$ & - & - \\
\hline MeO-4' & 55.18 & $3.71(\mathrm{~s})$ & 55.25 & $3.73(\mathrm{~s})$ & 55.17 & $3.73(\mathrm{~s})$ \\
\hline $\mathrm{HO}-7$ & - & $6.87(\mathrm{~s})$ & - & - & - & - \\
\hline $\mathrm{HO}-5$ & - & - & - & $5.16(\mathrm{~s})$ & - & - \\
\hline $1 "$ & - & - & - & - & 126.65 & - \\
\hline $2 ", 6 ”$ & - & - & - & - & 130.07 & $7.52(\mathrm{~d}, \mathrm{~J}=8.6)$ \\
\hline $3 ", 5 ”$ & - & - & - & - & 114.39 & $6.92(\mathrm{~d}, \mathrm{~J}=8.6)$ \\
\hline $4 "$ & - & - & - & - & 161.78 & - \\
\hline 7" & - & - & - & - & 146.73 & $7.81(\mathrm{~d},=15.9)$ \\
\hline $8 "$ & - & - & - & - & 114.04 & $6.47(\mathrm{~d},=15.9)$ \\
\hline $9 "$ & - & - & - & - & 165.45 & - \\
\hline MeO-4” & - & - & - & - & 55.35 & $3.83(\mathrm{~s})$ \\
\hline
\end{tabular}

*Multiplicity of the carbon-13 signals was deduced by comparison with the PND- and DEPT - ${ }^{13} \mathrm{C}-\mathrm{NMR}$ spectra. 
Table 2. ${ }^{13} \mathrm{C}(50 \mathrm{MHz})$ NMR spectral data for compounds 7 and derivatives $\mathbf{7 a}$ and $\mathbf{7 b}$ [DMSO* and $\mathrm{CDCl}_{3}$ as solvent, TMS as internal standard, chemical shifts in $\delta(\mathrm{ppm})$, and coupling constants (J) in Hertz]*.

\begin{tabular}{|c|c|c|c|c|c|c|}
\hline \multirow[b]{2}{*}{$\mathrm{C}$} & \multicolumn{2}{|r|}{$7 *$} & \multicolumn{2}{|c|}{$7 \mathbf{a}$} & \multicolumn{2}{|c|}{$7 \mathbf{b}$} \\
\hline & $\delta_{\mathrm{C}}$ & $\delta_{\mathrm{H}}$ & $\delta_{\mathrm{C}}$ & $\delta_{\mathrm{H}}$ & $\delta_{\mathrm{C}}$ & $\delta_{\mathrm{H}}$ \\
\hline 2 & 166.96 & - & 165.97 & - & 166.84 & - \\
\hline \multirow[t]{2}{*}{3} & 36.96 & $3.31(\mathrm{~m})$ & 36.76 & $3.02(\mathrm{~m})$ & 35.68 & $3.06(\mathrm{~d}, \mathrm{~J}=5.0)$ \\
\hline & & $2.90($ br dd, $\mathrm{J}=14.3)$ & & & & \\
\hline 4 & 32.82 & $4.66(\mathrm{br} \mathrm{dd}, \mathrm{J}=5.4)$ & 33.95 & $4.90(\mathrm{~m})$ & 34.32 & $4.41(\mathrm{t}, \mathrm{J}=5.0)$ \\
\hline 5 & 155.13 & - & 155.55 & - & 153.03 & - \\
\hline 6 & 98.85 & $6.56(\mathrm{~s})$ & 95.25 & $6.62(\mathrm{~s})$ & 106.47 & $6.97(s)$ \\
\hline 7 & 151.95 & - & 148.08 & - & 147.30 & - \\
\hline 8 & 104.08 & - & 102.95 & - & 106.14 & - \\
\hline 9 & 154.58 & - & 158.90 & - & 158.15 & - \\
\hline 10 & 105.60 & - & 110.28 & - & 113.11 & - \\
\hline 1 ' & 132.92 & - & 132.19 & - & 130.25 & - \\
\hline $2^{\prime}, 6^{\prime}$ & 127.90 & $7.00(\mathrm{~d}, \mathrm{~J}=8.6)$ & 127.66 & $6.98(\mathrm{~d}, \mathrm{~J}=8.8)$ & 126.53 & $6.93(\mathrm{~d}, \mathrm{~J}=8.8)$ \\
\hline $3^{\prime}, 5^{\prime}$ & 114.45 & $6.85(\mathrm{~d}, \mathrm{~J}=8.6)$ & 114.40 & $6.79(\mathrm{~d}, \mathrm{~J}=8.8)$ & 113.64 & $6.44(\mathrm{~d}, \mathrm{~J}=9.8)$ \\
\hline $4^{\prime}$ & 158.45 & - & 159.34 & - & 158.68 & - \\
\hline 2, & 159.95 & - & 160.57 & - & 164.04 & - \\
\hline $3^{\prime \prime}$ & 112.02 & $6.25(\mathrm{~d}, \mathrm{~J}=9.7)$ & 113.08 & $6.29(\mathrm{~d}, \mathrm{~J}=9.7)$ & 115.12 & $6.44(\mathrm{~d}, \mathrm{~J}==9.8)$ \\
\hline $4^{\prime}$, & 139.44 & $8.08(\mathrm{~d}, \mathrm{~J}=9.7)$ & 137.45 & $8.04(\mathrm{~d}, \mathrm{~J}=9.7)$ & 135.72 & $8.09(\mathrm{~d}, \mathrm{~J}==9.8)$ \\
\hline MeO-4' & 55.18 & $3.68(\mathrm{~s})$ & 55.23 & $3.75(\mathrm{~s})$ & 54.24 & $3.74(\mathrm{~s})$ \\
\hline $\mathrm{MeO}-5$ & - & - & 56.42 & $3.85(\mathrm{~s})$ & - & - \\
\hline $\mathrm{MeCO}$ & - & - & - & - & 19.66 & $2.17(\mathrm{~s})$ \\
\hline
\end{tabular}

$6.62(7 \mathbf{a})=0.35 \mathrm{ppm}], \mathrm{C}-6\left[\Delta \delta_{\mathrm{C}}=106.47(\mathbf{7 b})-95.25(\mathbf{7 a})\right.$

$=11.22 \mathrm{ppm}], \mathrm{C}-10\left[\Delta \delta_{\mathrm{C}}=113.11(\mathbf{7 b})-110.28(\mathbf{7 a})=2.83\right.$ ppm $]$ and $\mathrm{C}-8\left[\Delta \delta_{\mathrm{C}}=106.14(\mathbf{7 b})-102.95(\mathbf{1 7 a})=3.19\right.$ $\mathrm{ppm}]$ in the comparative analysis of the ${ }^{1} \mathrm{H}$ and ${ }^{13} \mathrm{CNMR}$ of the derivatives $\mathbf{7 a}$ and $\mathbf{7 b}$ in combination with the homonuclear ${ }^{1} \mathrm{H}\left\{{ }^{1} \mathrm{H}\right\}$ - nOe difference spectra performed with specific resonance of the methoxyl group at C-5 $\left(\delta_{\mathrm{H}}\right.$ 3.85) of 7a, which induced a signal enhancement of H-6 $\left(\delta_{\mathrm{H}} 6.62, \mathrm{nOe}=11 \%\right)$.

Cardanol is a mixture of 3-pentadecylphenols, differing in number and position of double bonds in the side chain ${ }^{15}$. This mixture is obtained from the cashew nut shell liquid (CNSL) of Anacardium occidentale. CNSL is a by-product of the cashew nut processing industries. A similar condensation of hydrogenated cardanol (6) with 4-methoxycinnamic acid chloride afforded 7-pentadecyl-4-(4-methoxyphenyl)-3,4-dihydrocoumarin (8), which was characterized by the ${ }^{1} \mathrm{H}$ and ${ }^{13} \mathrm{C}$ NMR spectra described in Table 3. The compound 7-hydroxy-5-methyl-4-(4-methoxyphenyl)-3,4-dihydroco umarin (1) displayed in vitro activity against Tripanosoma cruzi, and the corresponding cinnamic ester (3) did not show any activity against this microorganism ${ }^{16}$.

\section{Experimental}

General experimental procedures - Melting points were measured on a Kofler Hotstage and are uncorrected. ${ }^{1} \mathrm{H}-$ and ${ }^{13} \mathrm{C}$-NMR spectra were recorded on a Brucker WH-200 Mhz.

Synthesis of neoflavonoids 7-hydroxy-5-methyl4-(4'-methoxyphenyl)-3,4-dihydrocoumarin (1) and 5-Hydroxy-7-methyl-4-(4'-methoxyphenyl)-3,4-dihydroc oumarin (2)

A mixture of orcinol $(533 \mathrm{mg}, 4.3 \mathrm{mmol})$, aluminium trichloride $(667 \mathrm{mg}, 5.0 \mathrm{mmol})$ and 4-methoxycinnamic acid chloride $(786 \mathrm{mg}, 4.0 \mathrm{mmol})$ in carbon disulfide $(15 \mathrm{~mL})$ was stirred for three days at room temperature. The product was purified by silica gel column chromatography. The fraction eluted with hexane:chloroform (20:80) afforded an amorphous solid (2, $15 \mathrm{mg}, 0.67 \%$. m.p.: 148.8-149.7 ${ }^{\circ} \mathrm{C}$; for NMR spectral data see Table 1). The 
Table 3. ${ }^{1} \mathrm{H}(200 \mathrm{MHz})$ and ${ }^{13} \mathrm{C}(50 \mathrm{MHz})$ NMR spectral data of cardanol $(\mathbf{6})$ and the acetyl derivative $(\mathbf{8})\left[\mathrm{CDCl}_{3}\right.$ as solvent, TMS as internal standard, chemical shifts in $\delta(\mathrm{ppm})$, and coupling constants $(\mathrm{J})$ in Hertz]*.

\begin{tabular}{|c|c|c|c|c|c|}
\hline \multicolumn{4}{|c|}{8} & \multicolumn{2}{|c|}{ Hydrogenated cardanol 6} \\
\hline $\mathrm{C}$ & $\delta c$ & $\delta_{\mathrm{H}}, \mathrm{J}(\mathrm{Hz})$ & $\mathrm{C}$ & $\delta \mathrm{c}$ & $\delta_{\mathrm{H}}, \mathrm{J}(\mathrm{Hz})$ \\
\hline 2 & 167.99 & & 1 & 155.19 & - \\
\hline 3 & 37.32 & - & 2 & 115.39 & $6.70(\mathrm{~s})$ \\
\hline 4 & 39.60 & & 3 & 144.41 & - \\
\hline 5 & 127.89 & $4.24(\mathrm{dd}, \mathrm{J}=3.5,5.3)$ & 4 & 121.03 & $6.78(\mathrm{~d}, \mathrm{~J}=7.5)$ \\
\hline 6 & 124.64 & 6.92-6.81 (m) & 5 & 129.37 & $7.19(\mathrm{t}, \mathrm{J}=7.5)$ \\
\hline 7 & 144.10 & - & 6 & 112.56 & $6.48(\mathrm{~d}, \mathrm{~J}=7.5)$ \\
\hline 8 & 116.71 & $6.92-6.81(\mathrm{~m})$ & - & - & - \\
\hline 9 & 151.49 & - & - & - & - \\
\hline 10 & 123.20 & - & - & - & \\
\hline 1 ' & 132.47 & - & - & - & - \\
\hline $2^{\prime}, 6^{\prime}$ & 128.56 & $7.06(\mathrm{~d}, \mathrm{~J}=8.6)$ & - & - & - \\
\hline $3^{\prime}, 5^{\prime}$ & 114.37 & $6.94(\mathrm{~d}, \mathrm{~J}=8.6)$ & - & - & - \\
\hline 4 & 158.87 & - & & - & - \\
\hline $\mathrm{OMe}$ & 55.22 & $3.78(\mathrm{~s})$ & - & - & - \\
\hline $1 "$ & 35.43 & $2.58(\mathrm{t}, \mathrm{J}=8.0)$ & 1 & 35.83 & $2.57(\mathrm{t}, \mathrm{J}=8.0)$ \\
\hline $2^{\prime \prime}$ & 31.88 & $1.58(\mathrm{~m})$ & 2 & 31.30 & $1.58(\mathrm{~m})$ \\
\hline 3"-12" & $29.33-29.64$ & 1.24 (br s) & 3- 12 & 29.54 & 1.24 (br s) \\
\hline $13^{\prime \prime}$ & 31.88 & $1.24(\mathrm{br} \mathrm{s})$ & 13 & 31.94 & $1.24(\mathrm{br} \mathrm{s})$ \\
\hline $14 "$ & 22.65 & 1.24 (br s) & 14 & 22.70 & $1.24(\mathrm{br} \mathrm{s})$ \\
\hline 15 & 14.09 & $0.86(\mathrm{t}, \mathrm{J}=6.4)$ & 15 & 14.11 & $0.93(\mathrm{t}, \mathrm{J}=6.7)$ \\
\hline
\end{tabular}

*Type of carbon atoms deduced by comparison with PND and DEPT- ${ }^{13} \mathrm{C}-\mathrm{NMR}$. Homonuclear ${ }^{1} \mathrm{Hx}{ }^{1} \mathrm{H}-\mathrm{COSY}$ 2D NMR. Chemical shifts and coupling constants $(\mathrm{J})$ of the hydrogen atoms were obtained from the ${ }^{1} \mathrm{H}-\mathrm{NMR}$ spectrum.

fraction eluted with chloroform:ethyl acetate 90:10 furnished a colorless solid (1, $416 \mathrm{mg}, 18.17 \%$, m.p.: 135.4-136.4 ${ }^{\circ} \mathrm{C}$; for NMR spectral data see Table 1$)$.

\section{5-Methyl-7-O-coumaroyl-4-(4'-methoxyphenyl)-3,4-dihy} drocoumarin (3)

A solution of orcinol (711 mg, $5.73 \mathrm{mmol})$, aluminium trichloride $(667 \mathrm{mg}, 5.0 \mathrm{mmol})$, and 4-methoxycinnamic acid chloride (786 mg, $4.0 \mathrm{mmol}$ ) in carbon disulfide $(15 \mathrm{~mL})$ was stirred for one hour at room temperature. Ice was added to the reaction mixture, and the precipitate formed was filtered and purified by silica gel column chromatography. A colorless solid was obtained. (3, $73 \mathrm{mg}$, $2.87 \%$, m.p.: $121.1-126.4{ }^{\circ} \mathrm{C}$ : for NMR spectral data see Table 1)

Synthesis of 5-hydroxy-4-(4'-methoxyphenyl)- $\alpha$-pirano$(6 ", 5 ": 7,8)-3,4$-dihydrocoumarin (7).

A mixture of 5,7-dihydroxycoumarin $(\mathbf{5}, 400 \mathrm{mg}$, $5.0 \mathrm{mmol})$ and aluminium trichloride $(1823 \mathrm{mg}, 13.7$ mmol) was added to freshly prepared 4-methoxycinnamic acid chloride dissolved in nitrobenzene $(30 \mathrm{~mL})$. The reaction was stirred for three days at room temperature, then the reaction vessel was placed in an ice bath for one day. Ice was added to the reaction mixture, and a precipitate formed that was purified by silica gel column chromatography. The fraction eluted with chloroform:ethyl acetate (90:10) yielded a light yellow powder 7 (33 mg, $1.93 \%$, m.p.: 244.8-248.5 ${ }^{\circ} \mathrm{C}$; for spectral data see Table 2 ).

\section{Methylation of 7}

A solution of $\mathrm{CH}_{2} \mathrm{~N}_{2}$ in diethyl ether was added to a solution of 7 (4.9 mg, $0.014 \mathrm{mmol}$ ) in diethyl ether, and the mixture was kept overnight. The residue obtained was chromatographed on silica gel. Upon concentration, the fraction eluted with chloroform-ethyl acetate (95:05), gave a colorless solid (7a, 4.9 mg, 95.8 \%, m.p.: 228.4-229.6 $\left.{ }^{\circ} \mathrm{C}\right)$.

\section{Acetylation of 7}

The compound 7 (18 $\mathrm{mg}, 0.053 \mathrm{mmol})$ was acetylated $\left(\mathrm{Ac}_{2} \mathrm{O}\right.$-py $\left.4: 1\right)$ at room temperature. The mixture was puri- 
fied by silica gel column chromatography. The fraction eluted with chloroform furnished $\mathbf{7 b}(8.5 \mathrm{mg}, 42.50 \%$, m.p.: $180.1-181.5^{\circ} \mathrm{C}$ ).

Isolation of Cashew nut shell liquid (CNSL) components

Technical CNSL was furnished by Companhia Industrial Óleos Nordeste (CIONE) situated in Fortaleza-Ceará, Brazil.

Cashew nut shell liquid was distilled under vacmum after heating for $2 \mathrm{~h}$ at $130-200{ }^{\circ} \mathrm{C}$ (to complete decarboxilation and dehydration ${ }^{17}$ ), giving a pale yellow oil that darkens after a few days. This oil was submitted to column chromatography. Cardanol was obtained when the eluent was pure hexane and cardol.

\section{3-Pentadecylphenol (6)}

Cardanol (4 g) was dissolved in $10 \mathrm{~mL}$ of absolute ethanol, and $10 \%$ palladium on carbon $(0.4 \mathrm{~g})$ was added. The mixture was hydrogenated under pressure for three days and a solid material was obtained (4 g, 98 \%, m.p.: 50-53 ${ }^{\circ} \mathrm{C}$; for NMR spectral data see Table 3.)

7-Pentadecyl-4-(4'-methoxyphenyl)-3,4-dihydrocoumari $n(8)$

3-Pentadecylphenol (860 mg, $2.82 \mathrm{mmol}$ ) and aluminium trichloride (667 mg, $4.35 \mathrm{mmol}$ ) were added to freshly prepared 4-methoxycinnamic acid chloride [4-methoxycinnamic acid (726 mg, $4.07 \mathrm{mmol}$ ) and oxalyl chloride $(2.23 \mathrm{~g}, 1.5 \mathrm{~mL}, 17.56 \mathrm{mmol})$ in carbon disulfide $(10 \mathrm{~mL})]$ and dissolved in nitrobenzene $(15 \mathrm{~mL})$. The reaction mixture was stirred for three days in an ice bath. After the usual work-up, a solid material was obtained and purified by silica gel column chromatography. The fraction eluted with hexane:chloroform 60:40 furnished a colorless solid 8 (111 mg, 8.47 \% yield, m.p.: 86.7-87. ${ }^{\circ} \mathrm{C}$; for spectral data see Table 3$)$.

The compound 7-hydroxy-5-methyl-4-(4-methoxyphenyl)-3,4-dihydrocoumarin (1) and the corresponding cinnamic ester (3) were tested against Tripanosoma cruzi at the Instituto de Ciências Biológicas de Minas Gerais, Brazil.

\section{Aknowledgments}

The authors thank UFRRJ for NMR spectral data, and CNPq, CAPES, and FUNCAP for financial support and fellowships (CNPq).

\section{References}

1. Eyton, W.B.; Ollis, W.D.; Sutherland, I.O.; Gottlieb, O.R.; Taveira Magalhães, M.; Jackman, L.M. Tetrahedron 1966, 21, 2683.

2. Subramanyam, M.; Subra Rao, R.; Subra Rao, N.V. In Proceedings of the Indian Academy of Sciences 1974, 79 (Sec A), 223.

3. Ravelonjato, B.; Libot, F.; Ramiandrosoa, F.; Kunesch, N.; Gayral, P.; Poisson, J. Planta Med. 1992, 58, 51.

4. Ahluwalia, V.K.; Mukherjee, I.; Rani, N. Indian J. Chem. 1981, 918.

5. Asai, F.; Iinuma, T.; Tanaka, T.; Mizuno, M. Chem. Pharm. Bull. 1990, 38, 1079.

6. Simpson, J.D.; Stephen, H. J. Chem. Soc. 1956, 1382.

7. Krajnak, E.R.; Ritchie, E.; Taylor, W.C. Aust. J. Chem. 1973, 26, 899.

8. Talapatra, B.; Talapatra, S. Indian J. Chem. 1986, 25 B, 1122.

9. Furniss, B.S.; Hannaford, A.J.; Smith, P.W.G.; Tatchell, A.R. In Vogel's Textbook of Practical Organic Chemistry; John Wiley \& Sons; New York, 1989, p 1041.

10. Meinwald, J.; Shelton, J.C.; Buchnan, G.L.; Courtin, A. J. Org. Chem 1968, 33, 99.

11. Wehrl, F.W.; Wirthlin, T. In Interpretation of carbon-13 NMR Spectra; Heyden \& Sons; London, 1980; p 37.

12. Sanders, J.K.M.; Hunter, B.K. In Modern NMR Spectroscopy: A Guide for Chemists; Oxford University Press; Oxford, 1993, p 177.

13. Kaufman, K.D.; Kelly, R.C. J. Heterocyclic Chem. 1965, 2, 91.

14. Rhinesmith, H.S. J. Org. Chem. 1975, 40, 1773.

15. Tyman, J.H.P.; Chem. Soc. Rev. 1979, 8, 499.

16. Personal communication from Prof. Egler Chiari of the Instituto de Ciências Biológicas de Minas Gerais.

17. Harvey, M.T.; Caplan, S. Ind. Eng. Chem. 1940, 32, 4306. 